\title{
The relationship between lymphocyte / monocyte ratio and short-term mortality in acute ischemic stroke patients
}

\section{Akut iskemik inmeli hastalarda lenfosit/monosit oranın kısa dönem mortalite ile ilişkisi.}

\author{
Asli Bolayir
}

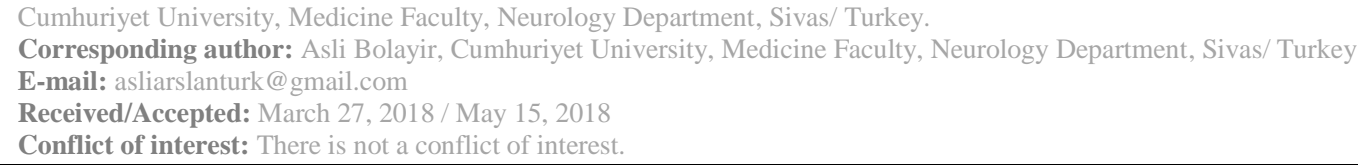

\section{SUMMARY}

Objective: The lymphocyte / monocyte ratio (LMR) obtained by dividing the number of lymphocytes by monocyte number is considered a new marker of inflammation. Recent studies have found an inverse relationship between LMR levels and 3-month functional recovery after acute ischemic stroke (AIS). Our aim in this study is to determine the role of LMR in the short-term mortality of AIS patients.

Method: Our study is a single centered retrospective study. 508 patients with AIS, who presented to our clinic between January 2011 and December 2017 and 512 healthy control with similar age and sex were included to our study.

Results: While monocyte count was higher in the patient group; lymphocyte count and LMR levels were higher in the control group. The patient group was then divided into two subgroups according to 30-day mortality. When the patients in the first group survivied $(\mathrm{n}=396)$, the patients in the second group died within 30 days after AIS $(n=112)$. In the second group, the lymphocyte count and LMR levels were lower when the monocyte count was elevated $(\mathrm{p}<0.001)$. Logistic regression analysis showed that uric acid, CRP and LMR are independent variables for the occurrence of 30-day mortality. In addition, ROC analysis revealed that an LMR value below 2.95 can be used as a marker for the short-term mortality of AIS (AUC:0.77, \%95 CI:0.67- 0.86,sensitivity:\%72.6, specificity: \%80.7).

Conclusions: Based on our results, it can be concluded that lower LMO levels in patients with AIS are related to shortterm mortality.

Keywords: white blood cell subtypes, lymphocyte/ monocyte ratio, inflammation, mortality, acute ischemic stroke

\section{ÖZET}

Amaç: Lenfosit sayısının monosit sayısına bölünmesi ile elde edilen lenfosit/ monosit oranı(LMO) inflamasyonu göstermede yeni bir belirteç olarak kabul edilmektedir. Son çalışmalar, LMO düzeyleri ile akut iskemik inme (AIİ) sonrası 3 aylık fonksiyonel iyileşme arasında ters bir ilişki olduğunu saptamıştır. Bu çalışmadaki amacımız LMO'nun Aİ̇ hastalarının kısa dönem mortalitesini göstermedeki rolünü saptamaktır.

Yöntem: Çalışmamız tek merkezli retrospektif bir çalışmadır. Ocak 2011 - Aralık 2017 yılları arasında kliniğimizde AIII tanısı ile izlenmiş 508 hasta ile benzer yaş ve cinsiyete sahip 512 kontrol çalışmamıza dahil edildi.

Bulgular: Monosit sayıs1 hasta grubunda yüksekken lenfosit sayıs1 ve LMO düzeyleri kontrol grubunda yüksek saptand1. Hasta grubu daha sonra 30 günlük mortaliteye göre iki alt gruba ayrıldı. İlk grupta hayatta kalan hastalar varken(n=396) ikinci gruptaki hastalar AİI sonrası 30 gün içinde exitus olmuştu(n=112). Bu iki grup kıyaslandığında; ikinci grupta lenfosit sayısı ve LMO düzeyleri düşükken, monosit sayısı yüksekti ( $p<0.001$ ). AIİ sonrası 30 günlük mortalite ile ilişkili risk faktörlerini belirlemek için yapılan lojistik regresyon analizi ürik asit, CRP ve LMO'nun mortalite gelişimi için bağımsız değişkenler olduğunu ortaya koydu. Ayrıca işlem karakteristiği eğrisi analizi ile LMO için 2.95 'in altındaki 
değerlerin Aî̇'ye bağl1 30 günlük mortaliteyi saptamada kullanılabileceği gösterildi (EAA:0.77, \%95 GA:0.670.86,duyarlılık:\%72.6,seçicilik:\%80.7).

Sonuç: Sonuçlarımıza dayanarak AIİ’'li hastalardaki düşük LMO düzeylerinin kısa dönem mortalite ile ilişkili olduğu söylenebilir.

Anahtar sözcükler: beyaz küre alt tipleri, lenfosit/monosit oranı, inflamasyon, mortalite, akut iskemik inme

\section{INTRODUCTION}

Acute ischemic stroke (AIS) with high mortality and morbidity rates is defined as infarction due to occlusion of cerebral arteries and is the most common neurological cause of emergency admission. It accounts for $80 \%$ to $85 \%$ of all cerebrovascular diseases ${ }^{1}$.

AIS triggers a very complex cascade of molecular and cellular events that are closely related to each other ${ }^{2}$. The inflammatory response is one of the major critical factors contributing to the pathophysiological process of AIS. Some inflammatory markers such as C-reactive protein (CRP) and fibrinogen are known to correlate with ischemic stroke prognosis ${ }^{2}$. Increased evidence suggests that white blood cell subtypes can also be used as an indicator of inflammation ${ }^{3}$.

It has been shown that lymphocyte count may decrease in patients with AIS after ischemia ${ }^{3,4}$. The suppression of lymphocyte count is thought to be secondary to lymphocyte apoptosis and redistribution of lymphocytes to lymphatic organs that is inducedby stress after ischemia. It has also been revealed that the reduction in lymphocyte count is associated with poor prognosis after AIS and has a negative role in long-term functional recovery.

It is considered that microglial cells that are active rapidly and time-lately after ischemia are major cells contributing to inflammation after injury. It is known that monocytes increase in peripheral blood level after AIS, then migrate to the infarct zone and contribute to the expansion of the ischemic lesion ${ }^{1,5}$.

Lymphocyte / monocyte ratio (LMR),a new indicator of basal inflammatory response, has recently been implicated in many types of malignancy ${ }^{6,7}$ Additionally, low LMR levels have been shown to be closely related to the severity of coronary artery disease ${ }^{8}$. Recent studies have revealed low LMR levels after AIS, which was inversely correlated with neurological disability 3 months after AIS ${ }^{9}$.It has been identified that, some of the white blood cell subtypes are associated with the mortality due to cerebrovascular diseases ${ }^{10}$. However, the association of LMR with mortality in patients with AIS is unknown.
In this study, our aim was to retrospectively compare the LMR values between patients with AIS and controls and to determine the role of LMR in the short-term mortality of patients with AIS.

\section{MATERIAL AND METHODS}

\section{Study Population:}

Our study is a single-center retrospective study that included 508 patients who were referred to our clinic within the first $24 \mathrm{~h}$ of symptoms and diagnosed with AIS between January 2011 and December 2017. The medical history, cranial magnetic resonance (MR), or computed tomography (CT) imaging findings showed the newly occurred ischemic lesion, and the neurological examination findings of patients were used in order to determine the definitive diagnosis of AIS. There were no restrictions regarding sex and age among the patients. Exclusion criteria were younger than 18 years, systematic acute/chronic inflammatory/autoimmune diseases, history of infection within 2 weeks before admission, chronic connective tissue diseases, hematological disorders, cancer, severe liver, kidney or heart failure, acute coronary syndrome within the past three months, prior acute myocardial infarction, a history of major surgery or trauma, chronic alcohol abuse and using immunosuppressants, antiinflammatories or steroids. The patient group was divided into two subgroups according to the 30-day patient mortality. The patients in the first group were survivors past 30 days, and patients in the second group were patients who died within 30 days after AIS. Stroke subtypes were assorted according to the TOAST classification, including large-artery atherosclerosis, small-artery occlusion, cardioembolism, stroke of other determined etiology, and stroke of undetermined etiology ${ }^{11}$.

The control group consisted of 512 patients who were age-and gender-matched and gave blood samples for reasons other than AIS between January 2011 and December 2017. These patients did not suffer from any uncontrolled systemic diseases such as diabetes mellitus, hypertension, cardiovascular diseases or cancer. 
All patients included in the current study were examined and investigated in terms of parameters such as age, gender, diabetes mellitus (defined as the fasting blood glucose level above $126 \mathrm{mg} / \mathrm{dl}$ and/or the use of antidiabetic therapy), hypertension (defined as the systolic blood pressure above $140 \mathrm{mmHg}$ and/or the diastolic blood pressure above $90 \mathrm{mmHg}$, or the use of antihypertensive therapy), hyperlipidemia (defined as the fasting total cholesterol value above 200 $\mathrm{mg} / \mathrm{dl}$ and/or the triglyceride value above 150 $\mathrm{mg} / \mathrm{dl}$ (National Cholesterol Education Program Adult Treatment Panel III guideline)),smoking history (current smoker or having quit in the last 6 months),statin use, glucose, plasma creatinine, uric acid, C-reactive protein (CRP), total cholesterol, low-density lipoprotein, low-density lipoprotein, triglyceride levels, hemoglobin, monocyte, lymphocyte, neutrophil and white blood cell (WBC) counts, LMR values and 30-day mortality.

The missing information in our retrospective study was obtained via telephone interview with patients or their relatives.

Approval by the ethics committee of Cumhuriyet University was obtained for this study.

\section{Evaluation of biochemical and hematological parameters:}

Blood samples of patients were collected within the first $24 \mathrm{~h}$ following AIS. Dry tubes were used for the biochemical analysis, and EDTA tubes were used for the hematological test. Whole blood counts of patient and control groups were analyzed with a Mindray BC- 6800 device using Diagon Kits. The LMR values were determined by dividing the number of lymphocytes by the number of monocytes. Biochemical analyses were performed with a Beckman Coulter AU5800 device (Beckman Coulter Inc, Hialeah, Florida) using kits produced by the same company via a fully automatic nephelometric method.

\section{Statistical analysis:}

Data obtained from this study was evaluated by using the SPSS 22.0 program. Continuous data were expressed as the mean \pm standard deviation; categorical data were expressed as percentage (\%). Data were evaluated with the KolmogorovSmirnov test in terms of normal distribution. The use of an independent T-test for the analysis of continuous data showing normal distribution and a Mann-Whitney U-test for the analysis of variables not showing normal distribution were planned. However, continuous data obtained from two different groups did not show normal distribution, therefore, the Mann-Whitney U-test was used for the analysis. Logistic regression analysis was used to determine the independent risk factors for the 30-day mortality of patients with AIS. Receiver operating characteristic curve (ROC) analysis was used for determining the optimum cut-off value of LMR for predicting the 30-day mortality of AIS. The statistical significance level was accepted as $p$ $<0.05$.

\section{RESULTS}

Comparison of the patient and control groups in terms of baseline demographic characteristics revealed that there was no significant difference between the two groups in terms of age, gender, diabetes mellitus status, hypertensive status, statin use, and smoking status. The mean age of the patients was $78.02 \pm 6.5$, while the control group was $78.11 \pm 8.4$ years. When the patient and control groups were compared in terms of laboratory parameters, there was no significant difference between the two groups in terms of glucose, creatinine, hemoglobin, HDL, LDL and total cholesterol levels $(p=0.34, p=0.10, p=0.52, p=$ $0.43, p=0.12$ and $p=0.39$, respectively). On the other hand, there were significant differences between the two groups in terms of uric acid, CRP, monocyte, lymphocyte, neutrophil and white blood cell (WBC) counts and LMR values. While uric acid, CRP, monocyte, neutrophil and WBC counts were higher in the patient group, the lymphocyte count and the LMR values were significantly higher in the control group (Table 1). Patients with ischemic stroke were classified into two groups according to the 30-day mortality. The first group survived( $n=396)$, while patients in the second group died within 30 days after $\operatorname{AIS}(n=112)$. The comparison of the two groups in terms of lymphocyte and monocyte counts and LMR value demonstrated that monocyte count of the second group were statistically higher, while the lymphocyte count and LMR value was statistically lower compared to the first group ( $\mathrm{p}<0.001$ ) (Table 2). Logistic regression analysis to determine the risk factors associated with 30-day mortality after AIS revealed that uric acid, CRP and LMR are independent variables for the occurrence of short-term mortality (Table 3 ). 
Table 1. Comparison of the baseline demographic, clinical and laboratory characteristics of the control and the patients groups.

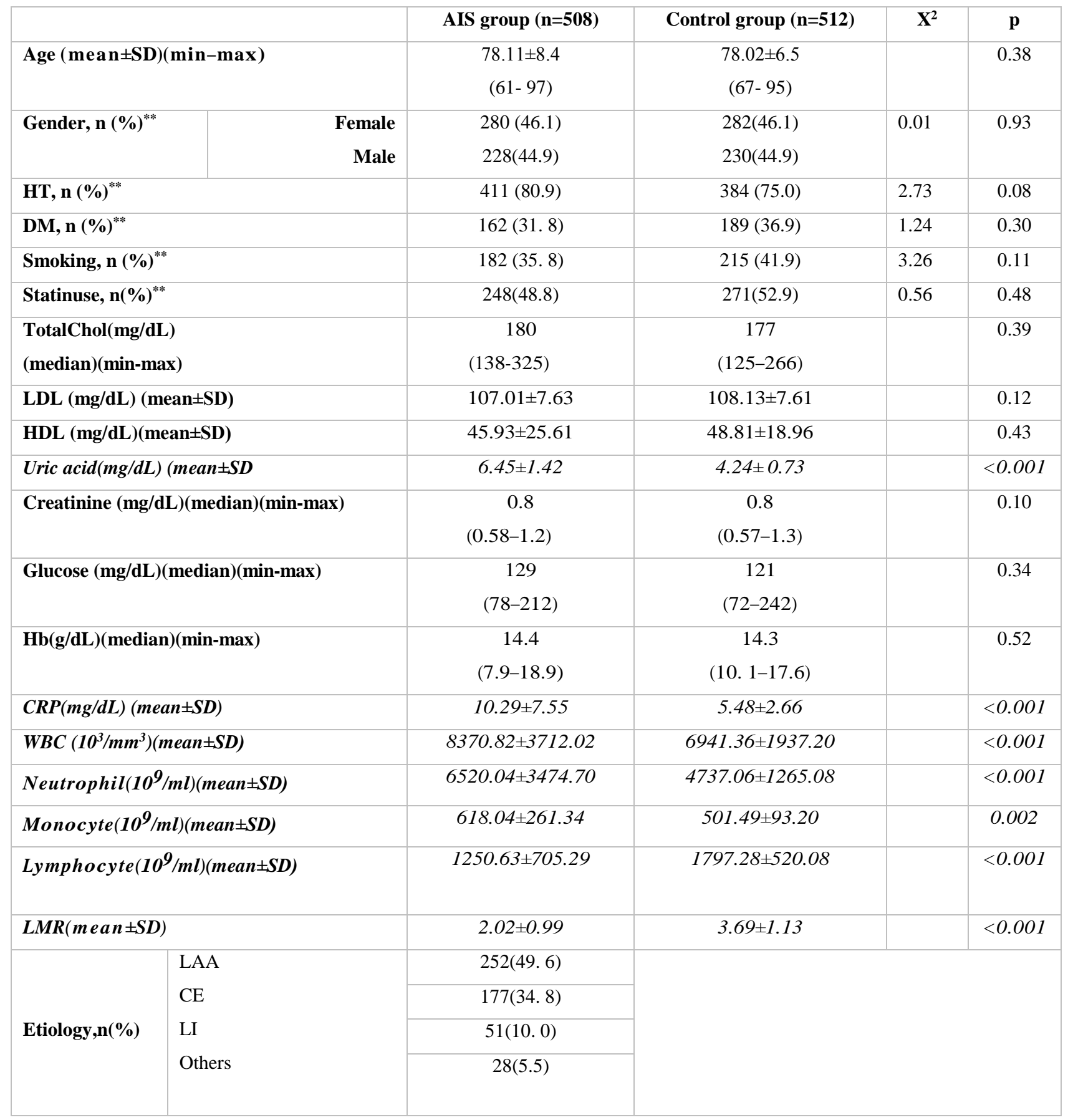

Italic values are used to demonstrate the statistical significance. **: Chi square test used. Abbreviations: CRP: C- reactive protein, DM: diabetes mellitus, Hb: hemoglobin, HDL high density lipoprotein, HT: hypertension, LDL: low density lipoprotein, LMR: lymphocyte to monocyte ratio, TotalCho: total cholestrol, SD: stamdard deviation, WBC: white blood cell. 
Table 2. Comparison of the mean lymphocyte and monocyte counts and LMR values in patient group after classification into subgroups according to the mortality within 30-day period.

\begin{tabular}{|l|l|l|l|}
\hline & $\begin{array}{l}\text { Surviving } \\
\text { group(n=396) }\end{array}$ & $\begin{array}{l}\text { Non-surviving group } \\
(\mathbf{n = 1 1 2})\end{array}$ & $\mathbf{p}$ \\
\hline Monocyte $(\mathbf{1 0} \mathbf{9} / \mathbf{m l})($ mean \pm SD) & $534.23 \pm 10.99$ & $825.46 \pm 46.22$ & $<0.001$ \\
\hline Lymphocyte $(\mathbf{1 0} / \mathbf{m l})($ mean \pm SD) & $1169.43 \pm 502.89$ & $1440.70 \pm 703.35$ & $<0.001$ \\
\hline LMR $($ mean \pm SD) & $2.19 \pm 1.12$ & $1.75 \pm 0.99$ & $<0.001$ \\
\hline
\end{tabular}

Italic values are used to demonstrate the statistical significance. Abbreviations: LMR: lymphocyte to monocyte ratio, SD: stamdard deviation.

Table 3. Logistic regression analysis of independent significant variables in the 30-day mortality in AIS.

\begin{tabular}{|l|l|l|l|l|l|}
\hline & $\mathbf{B}$ & $\mathbf{S E}$ & $\mathbf{p}$ & $\mathbf{E x p}(\mathbf{B})$ & $\mathbf{9 5 \%} \mathbf{C I}$ \\
\hline Uric acid & 2.59 & 0.68 & 0.001 & 13.86 & $3.65-52.65$ \\
\hline CRP & 0.64 & 0.18 & 0.001 & 1.88 & $1.32-2.69$ \\
\hline LMR & 1.85 & 0.41 & 0.001 & 6.32 & $2.84-14.04$ \\
\hline
\end{tabular}

Abbreviations: CI: confidence interval, CRP: C- reactive protein, LMR: lymphocyte to monocyte ratio, SE: stamdard error, $\beta$ : regression coefficient.

In addition, receiver operating characteristic curve (ROC) analysis was used for determining the optimum cut-off LMR value for predicting 30-day mortality in AIS patients. The area under the curve (AUC) value was calculated as $0.77(95 \%$ confidence interval (CI) 0.67-0.86). The cut-off LMR value was observed as 2.95 with a sensitivity of $72.6 \%$ and a specificity of $80.7 \%$ (Fig. 1).

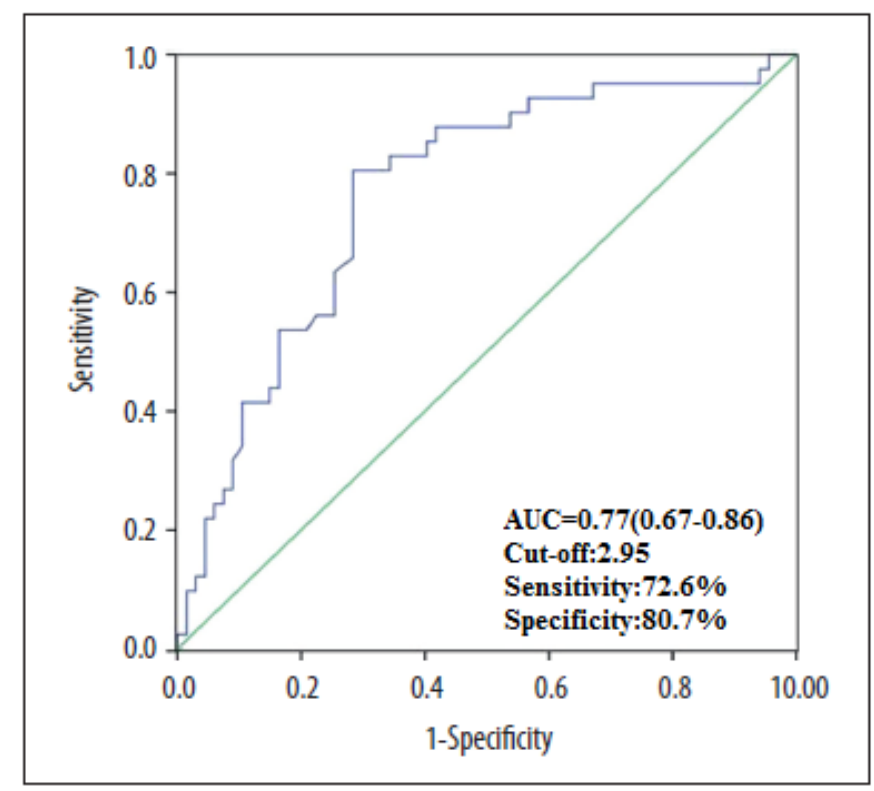

Figure 1: Receiver operating characteristic curve of LMR and 30-day mortality in acute ischemic stroke patients. 


\section{DISCUSSION}

To the best of our knowledge, our study is the first study which demonstrates the relationship between LMR and short term mortality in AIS patients. This study reveals that LMR within 24 hours keeps good predictive value for the short-term mortality of AIS and that lower levels of LMR are closely relevant with 30-day mortality due to AIS. Therefore, LMR can be considered as a novel prognostic predictor for AIS.

The inflammation response activated by brain ischemia is regarded as a damaging factor causing secondary brain injury ${ }^{12}$. The pathop-hysiological process after AIS is well understood to be attributed to leukocyte infiltration and release of many inflammatory mediators, contributing to secondary brain injury, which results in a poor prognosis in AIS patients ${ }^{12}$.

Recently, it has been showed that, the changes of lymphocyte count, subtypes of leukocytes, is associated with both cardiovascular diseases and other neurological diseases ${ }^{13}$. Lymphocytes have a controversial role in the inflammation after AIS. It was indicated with somerodent studies, that elevated lymphocytes increase anti-inflammatory cytokine, interleukin (IL)-10, and suppress inflammatory cytokines, such as IL-6 and tumor necrosis factor (TNF)- $\alpha$, stimulating neuroprotective effect ${ }^{14}$.

Shortly, lymphocytosis is beneficial to reduce brain infarct and attenuate neurological deficits. Several clinical studies showed low lymphocyte counts after AIS, and this reduction is associated with poor prognosis and mortality in AIS patients, which is consisted our results. It is accepted that reduced lymphocyte counts after AIS are due to lymphocyte apoptosis, which was induced by the release of cortisol, as a result of the systemic stress, resulting in the activation of the renin-angiotensin system ${ }^{15}$.

After arterial occlusion in brain tissue, microglias, which are brain resident macrophages, are activated within minutes ${ }^{1}$. Monocytes, which play particularly important role in prognosis after AIS, are recruited to the ischemic region. This revelaed several functional differences between monocytes subtypes in AIS. It showed that the count of the classical monocyte subtype(CD $\left.14^{++}, \mathrm{CD} 16\right)$, which has pro-inflammatory effect, was significantly increased in peripheral blood circulation, whereas the count of the non-classical monocyte subtype, which is accepted as antiinflmmatory monocyte subtype, significantly decreased in the acute phase of AIS, which is strongly correlated with the progression and severity of brain infarction ${ }^{1,9}$.In addition, clinical studies have shown that the increased count of classical monocytes, which begin to increase in the peripheral blood circulation within $3 \mathrm{~h}$ after AIS onset was associated with the severity of brain injury ${ }^{16}$. Therefore, it can be suggested that the prognosis of AIS patients with high monocytes counts at admisson may be worse than others, a finding similar to the results of our study.

Accordingly, LMR which is obtained by dividing the lymphocyte count by the monocyte count could be a new predictor of short-term mortality in AIS. We pronounced with this study that, the patients with AIS, having decreased LMR levels tend to die within 30 days. Additionally, the ROC curve demonstrated that an LMR lower than 2.95 predicted short-term mortality, with a sensitivity of 72 . 6\% and a specificity of $80.7 \%$, which revealed that LMR was a good indicator for the short-term mortality of AIS.

The underlying mechanisms between low LMR levels and the 30-day mortality in AIS are not clearly understood, but as mentioned above, it is known that lymphocytes acts in the antiinflammatory direction while monocytes act in the proinflammatory direction during the acute phase of AIS. Moreover, recent studies have suggested that inflmmatory processes following brain injury after AIS may contribute to a poor outcome ${ }^{1,9}$.

There are several limitations in our study. This is a single center retrospective study. So, the number of patients is relatively small. Our only end point is the 30-day mortality in AIS. There was no detailed evaluation according to the etiologic subtypes of AIS or causes of 30-day mortality. Only one LMR value was used in the current study; however the inflammatory process has continuity. Besides, the other inflammatory markers like TNF- $\alpha$, IL-1 and IL-6 were not measured.

\section{CONCLUSION}

In summary, our study demonstrated that patients with AIS have lower lymphocyte and higher monocyte counts and therefore, lower LMR values compared to control group. We also suggest that an LMR value below 2.95 is an independent risk factor for the short-term mortality of AIS patients. More detailed and exstensive multicenter prospective studies are needed to assess our findings. 


\section{REFERENCES}

1.Bolayir A,Gokce SF, Cigdem B, Bolayir HA, Kayim Yildiz O,Bolayir E,et al. Monocytes/highdensity lipoprotein ratio predicts the mortality in ischemic stroke. Neurologia i Neurochirurgia Polska 2018; 55: 150- 155.

2. Rodrigues SF, Granger DN. Leukocytemediated tissue injury in ischemic stroke. Curr Med Chem, 2014; 21: 2130-2137.

3.Kim J, Song TJ, Park JH, Lee HS, Nam CM, Nam HS, et al. Different prognostic value of white blood cell subtypes in patients with acute cerebral infarction. Atherosclerosis, 2012; 222: 464-467.

4. Pagram H, Bivard A, Lincz LF, Levi C. Peripheral immune cell counts and advanced imaging as biomarkers of stroke outcome. Cerebrovasc Dis Extra, 2016; 6: 120-128.

5. Liberale L, Montecucco F, Bonaventura A, Casetta I, Seraceni S, Trentini A, et al. Monocyte count at onset predicts post-stroke outcomes during a 90-day follow up. Eur J Clin Invest, 2017; 47(10): 702-710.

6.Zhu JY, Liu CC, Wang L, Zhong M, Tang HL, Wang H. Peripheral bloodlymphocyte-tomonocyte ratio as a prognostic factor inadvanced epithelial ovarian cancer: a multicenterretrospective study. J Cancer 2017;8:737-743.

7. Song W, Tian C, Wang K, Zhang RJ, Zou SB. The pretreatmentlymphocyte to monocyte ratio predicts clinical outcomefor patients with hepatocellular carcinoma: a meta-analysis.Sci Rep 2017;7:466-451.

8. Ji H, Li Y, Fan Z, Zuo B, Jian X, Li L, et al. Monocyte/lymphocyte ratio predicts the severity of coronary artery disease: a syntax score assessment. BMC Cardiovasc Disord 2017;17:90- 95.

9.Ren H, Liu X, Wang L, Gao Y. Lymphocyte-tomonocyte ratio: a novel predictor of the prognosis of acute ischemic stroke. Journal of Stroke And Cerebrovascular Diseases 2017; 26(11): 25952602

10.Bolayir A,Cigdem B, Gokce SF, Bolayir HA, Kayim Yildiz O,Bolayir E,et al. The Effect of Eosinopenia on Mortality in Patients with Intracerebral Hemorrhage. Journal of Stroke and Cerebrovascular Disease 2017;10(26):2248- 2255.

11. Adams HP Jr, Bendixen BH, Kappelle LJ, Biller J, Love BB, Gordon DL, et al. Classification of subtype of acute ischemic stroke. Definitions for use in a multicenter clinical trial. TOAST. Trial of
Org 10172 in Acute Stroke Treatment. Stroke 1993;24:35-41.

12. Anrather J, Iadecola C. Inflammation and stroke: an overview. Neurother 2016;13:661-670.

13. Bolayir A, Gokce SF. The role of mean platelet volume, platelet distrubition width and platelet/lymphocyte ration in development of cerebral venous thrombosis. Cumhuriyet Medical Journal 2017;39:683-691.

14.Liesz A, Suri-Payer E, Veltkamp C, Doerr H, Sommer C,Rivest $\mathrm{S}$, et al. Regulatory $\mathrm{T}$ cells are key cerebroprotective immunomodulators in acute experimental stroke. Nat Med 2009;15:192-199.

15. Chiu NL, Kaiser B, Nguyen YV, Welbourne S, Lall C, Crammer SC. The volume of the spleen and its correlates after acute stroke. J Stroke Cerebrovasc Dis 2016;25:2958-2961.

16. Urra X, Villamor N, Amaro S, Gomez-Choco M,Obach V, Oleaga L, et al. Monocyte subtypes predict clinical course and prognosis in human stroke. J Cereb Blood Flow Metab 2009;29:9941002. 